\title{
Nachni: The Saga of Art Unappreciated
}

Prof. Aparajita Hazra

Professor and Head

Department of English

Sidho-Kanho-Birsha University

West Bengal, India

dr.aparajitahazra@gmail.com

\begin{abstract}
The Nachni s of Purulia are a group of women dancers who dance to the characteristic Jhumur of rural Bengal. The dance form of the Nachni is without a doubt part of the cultural heritage of Bengal — and in a broader sense, of India. Yet, a closer look at the community would show up a distinctive lack of acknowledgement about this art form. On the contrary, these women, these dancers are most of the time stigmatized and looked down upon, so much so that these women themselves have come to see their profession as something not to be proud of. This paper proposes to talk of the Nachni s in the Rarh Bengal area-especially, Purulia-to unearth some not-so-pretty causes for the stigma that keeps these artisans of Nachni dance from holding their head high in society.
\end{abstract}

Keywords: Nachni, Jhumur, Dancer, Stigma, Rarh Bengal. 
Introduction:

Surulia, PO.-V. Nagar, PS-Purulia, Block Purulia - this was the address we searched out one fine day as I, along with some of my interested students, sought out the place where lives Postobala Karmakar - a Nachni who had bagged many accolades - the piece de resistance being the 'Lalan Purashkar' or Lalan Prize for the Arts that she won. We took in the quiet little village set aside a little away from the National Highway towards the outskirts of Purulia as I parked my car in the rough-hewn, dusty empty space in front of a one-roomed squat structure-supposed to be the office of an overwhelming sense of the reigning isolation struck me. Set away from the main town of Purulia, nestled into a corner of a barren empty field, Nachni Postubala Devi's living quarters seemed to reverberate symbolically and ironically with the emptiness and want of inclusion the Nachni life.

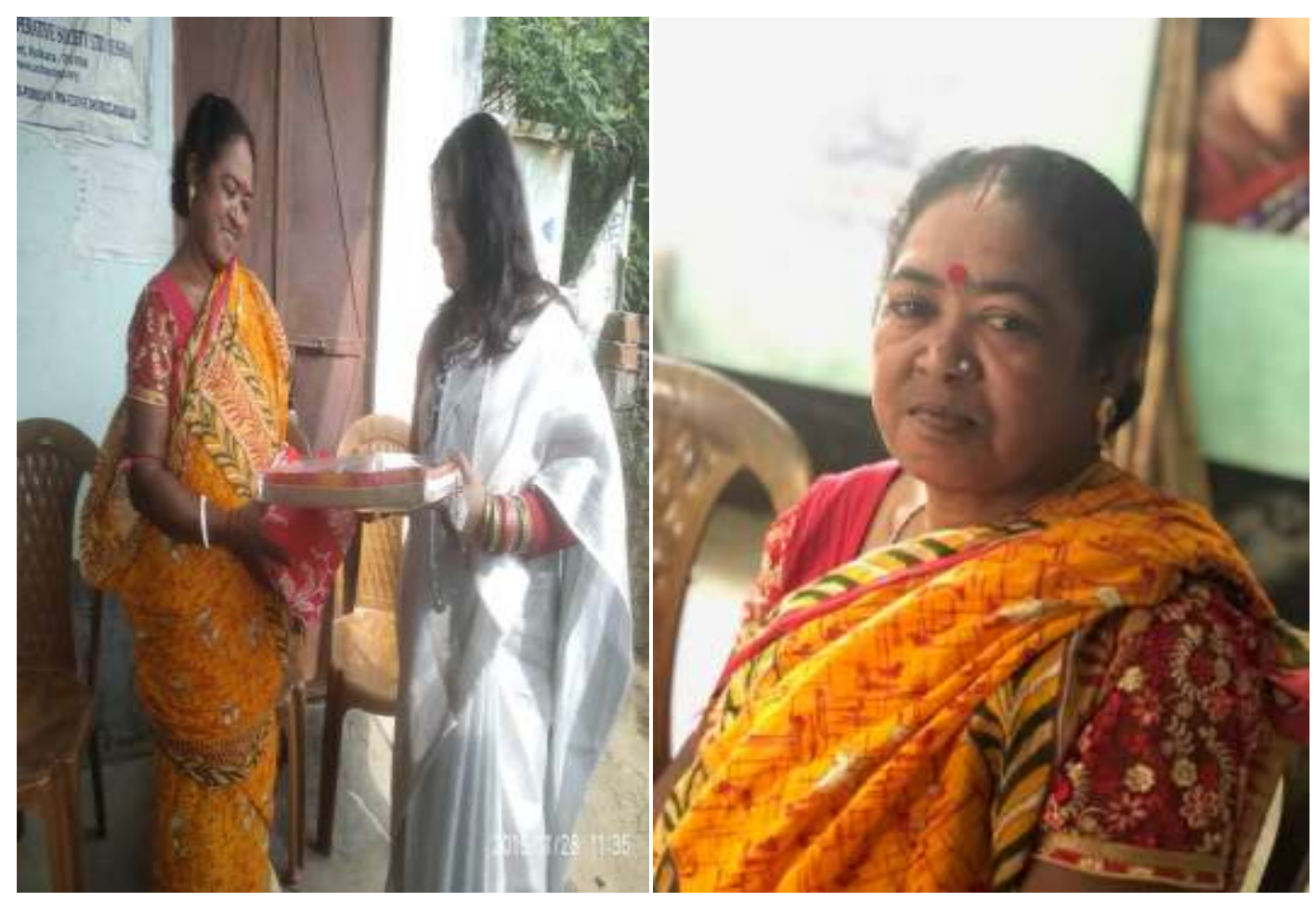

Nachni Postobala Karmakar 
Who are the Nachnis:

Nachni - the word is gradually fading into oblivion as a digitally accomplished world is more prone towards films and events or streamed on channels on their electronic devices or social media glitches on their handsets. Yet the back-of-the-beyonds of Purulia in West Bengal still hold on to vestiges of this rich cultural facet of this area of Bengal, better known as Rarh Bangla. And the Nachnis are still here, treasuring and habitually carrying on with a tradition that is on its way to oblivion unless sincere efforts are made to bring this up to the stature and recognition of intangible Heritage like Chhau, another art form of this area.

Curious to know more, I asked this soft spoken, amiably shy lady, whom I soon enough fell to calling Postu-di, some of the myriad questions that were flocking my mind. And in answer, she told me all about Nachni-and all about her own life as one.

\section{The Backdrop:}

In the down trodden echelons of society in and around Purulia, the girl child is most of the time relegated to the less-wanted class of offspring. Ten years back, the situation was even worse for the girl child. Girls were seldom educated and were considered immensely burdensome on the family as they would have to be married off young or else the father would have to bear the brunt of criticism from a judgmental society. And marrying off a girl would always cost a considerable dowry. Thus a girl child would often be considered burdensome as she was tantamount to expenditure and no income. Thus, unfortunately, girls were often just abandoned-sometimes outcast from the family-sometimes in severe ostracizing by the members of the family. Left to fend for themselves, the girls often resorted to leaving home in a bid to make out a living for themselves. Now, eking out a living without and formal education or 
training in any sort of skill development often left them with few choices. Many of them would seek refuge with who would be known as a 'Rasik'or kind of patron. A Rasik is a man who performs and sings Jhumur - a traditional vocal art form of the Chhota Nagpur plateau region. The songs normally pivot on the mythological tales of Radha and Krishna. Sung in the husky, and what could often be raucous to a sophisticated ear, loud voices of the Rasik, the Jhumur songs — often loaded with innuendos—-would elaborate on the love stories of Radha and Krishna. The Nachni, too, along with her dancing, would join in the singing — often bringing up the refrain following the lyrics voiced by the lead singer - the Rasik. The Nachni would dance along to the music of the Jhumur song, accompanied by the deep percussions of the Dholki and Nagara and the playing of the harmonium and the Shanai or Shehnai, sounding out the beat of the Taal on her Ghungroo - or Ghungur — as it is called in Bengali. The sound of the anklet bells or ghungur is what lends the name 'Jhumur' to this art form.

The Rasik

The Nachni has a 'Rasik'. The Raisik is the one who holds the strings in the entire ensemble of Nachni tradition. He runs the whole show. He is the one who brings the young, untrained girls from their impoverished impasse of life and trains them up. Most of the time, this partnership of art extends into real life as well, as the Nachni starts living together with her Rasik. The Rasik would often have a legally-wedded wife and children of his own. Thus there would be a subtle juggling of familial arrangements, as the Rasik would have to devise ways to keep his Nachni apart from his family, while all the time providing for her. The Rasik would thus, most of the time, maintain two households or more. The Nachni would perform — but the money earned would be taken over by the Rasik, who would take on the onus of upkeeping the 
Nachni. The peril involved would be that the Nachni, after living with and earning for her Rasik for a lifetime, could still be abandoned once age robbed her of her looks or her ability to dance and perform on stage, and thereby, her ability to earn money anymore. The mortification of being abandoned for a younger Nachni and having to find out desperate means to upkeep herself in old age is one insecurity that the Nachni forever has to negotiate.

The girls often come absolutely amateur and novice to the Rasik. The Rasik is the one who teaches the dance form to the girls. He teaches them the intricacies of how to sway along to the tunes of the Jhumur song and keep up the beat of the Dholki on their feet. The swaying hips and coy smiles that often accompany the dance form-something that lends this Nachni-tradition quite an amount of infamy as a not-so-acceptable-in sophisticated-society art form-often owes itself to the individual unique style of the Nachni herself. A lot of improvisation is done right on stage during the performance by both the Rasik and his Nachni. The tradition of Nachniperformed by girls who normally have no training whatsoever in any classical dance form-is basically a dance form aimed at providing entertainment and amusement to the moneyed class of Zamindars and landlords - who, ironically were the very ones who laid down rules in society to ostracise these very Nachnis that they cheer during their performances in the dark of night.

\section{The Roots:}

While talking of the Nachni, one is tempted to draw comparisons between these women whose art never really got to be acknowledged by what goes by the name of 'civilised' society, and those who got to be known as the 'Tawaif' in the days of yore.

Considering circumstances, one daresay that the Nachni could be traced back to the Tawaifs of the $18^{\text {th }}$ century. During the turn of the $18^{\text {th }}$ century, the Tawaif or the 
nautch-girl would be quite someone with the Mughal elite in Delhi and Lucknow. These Tawaifs also flourished a lot in Awadh, and further east in Varanasi and Calcutta where they were popular by the name of Baiji. When the East India Company proliferated in India, many of the early European officials even married local Tawaifs or kept them in their harems as courtesans. But as the country reeled under the Great Mutiny of 1857 , the Delhi and Awadh court came to be disbanded. On the other hand, as the era of Enlightenment made its way into Indian socio-cultural existence, and the emancipation of women came to become an issue of strife, the Tawaifs-what with their their taleem (training), or their tehzeeb (etiquette) and tameez (manners), metamorphosed into a symbol of medieval decadence.

But as days progressed and so did the cultural milieu of the land, the situation of the Tawaifs changed a lot. Though many a famous Tawaif and Baiji continued to dominate the urban socio-cultural scenario well into the 20 th century, their popularity took a serious beating with the coming of theatre, gramophone, radio and cinema and a plethora of new mediums of entertainment. Losing popularity necessarily meant losing means of income. So the changing social and cultural vista saw Tawaifs moving away into the suburbs and the countryside where technology was still scarce and people still would flock to their shows of popular singing and onstage acting. Slowly, the patrons changed from the Nawabs and rajahs to the Zamindars and Landlords of a hierarchic system who still were ready to upkeep these women for entertainment. Slowly, towards the countyside the Nachnis came to be a popular name. Away from centerpoints of thoroughbred classical Taleem like Delhi and Lucknow, these women made do with whatever training they got from Rasiks and careful observation and understanding of 
what would please the Zamindars and Babus. The Nachni evolved. But sadly enough, the social status that the tawaifs used to enjoy, was left behind with their Taleem and Rutwa in past of the yesteryears. The Nachnis became a coterie of impoverished and socially stigmatised outcasts.

\section{Life Story: Postubala Devi Karmakar:}

Postubala Devi — one of the most acclaimed among the Nachnis still alive in and around Purulia_-was born to a woman....., who was a Nachni. Her father was the Bajandar with her mother - the musician. Before Postubala was even born, they had formed this small team which went around performing to gatherings of rustic audiences in melas or fairs that would come up during the festivities of Durga Puja or Poush Sankranti. Eventually, the man and the woman married and Postubala was born. But enough, shortly after Postubala was born, when she was all of 2 r 3 months of age, her father passed away. And then, when she grew up to be of 3 or 4 years, characteristically enough, her mother, who, without her husband was probably hard pressed for money, left with another man-presumably another Bajandar or Rasik. Little Postubala was left in the ancestral home of the Sing-Sardars. She was brought up by her Jethu-her father's elder brother and his family. But soon enough, life turned its back on a hapless Postubala as her cousins began insufferable torment on her. She was reduced to begging around for money. Even then, whatever she begged and brought home was wrangled out of her hands by her cousins and she was rendered absolutely penniless. She had no food. All she got from her Jethu's family was a bit of the starch drained from cooked rice. Not a single morsel of rice too could make its way to her mouth. 'Bhaater phyan tuku petaam shudhu' she told me when I interviewed her, 'bhaat pai ni kono din'. Expectedly, she was terribly malnourished. Her body showed visible signs of it. 
Her stomach was distended and her wide big eyes stared hungrily out of her head that looked too big for her emaciated little body. People spread the word to her mother who was then living in a neighbouring village. The mother that she was-though estranged-Postobala's mother came to the ancestral home to find out what was wrong and probably to take Posto back with her. On inquiring, she was told that Postobala had 'Dhaat' - a rustic insinuation towards a venereal disease. And little Postobala was then all of 5 or 6 years of age.

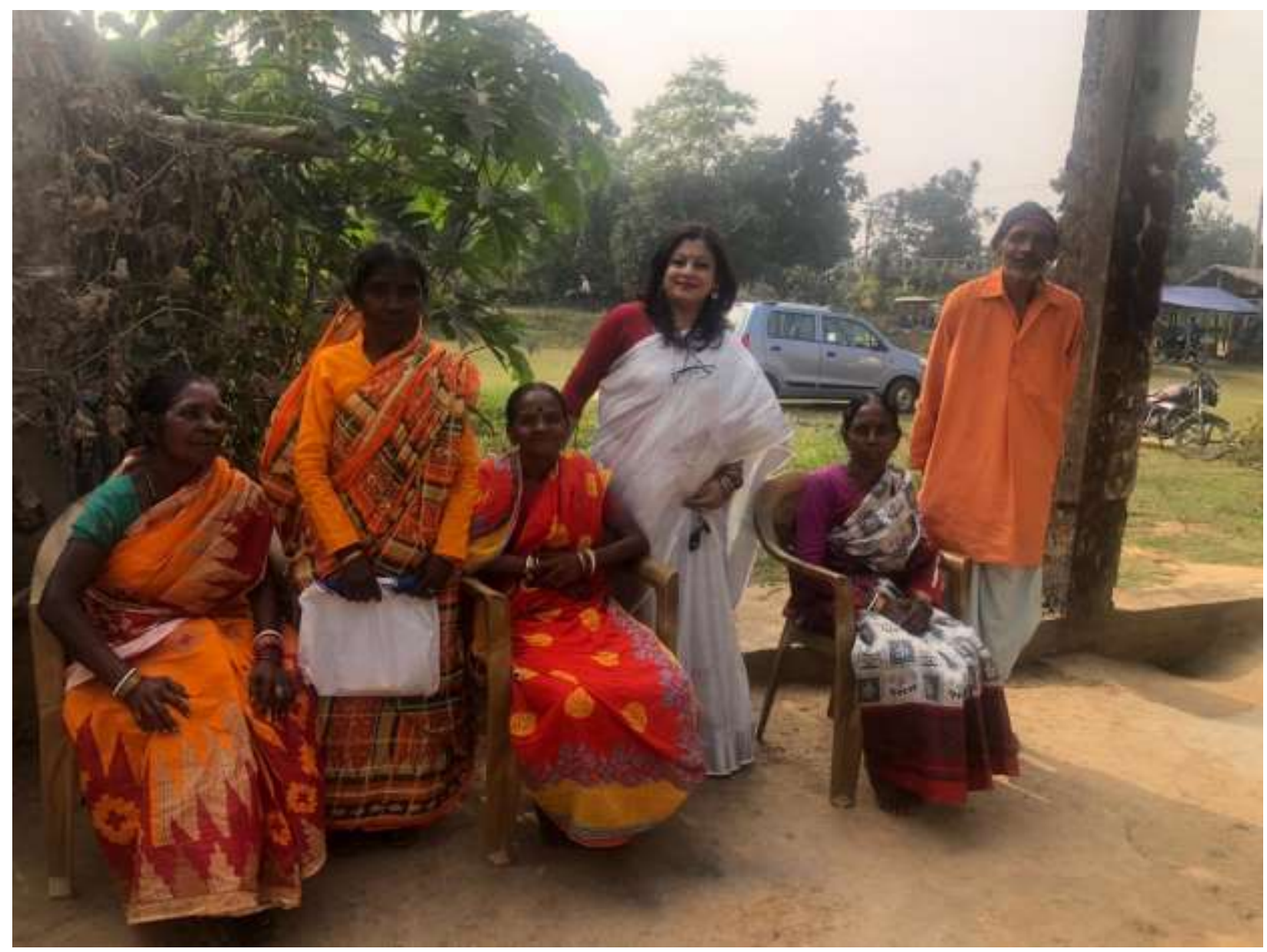

Prof Aparajita Hazra with some of the Nachnis of Purulia for interviewing them.

Postobala's mother took her to Burdwan where they worked arable land. Postobalawhile she was narrating her life- had a longing gleam in her eyes as she recalled how, for a very 
brief juncture, she knew peace as she trotted along with her mother to the fields to harvest. She remembers how her mother would cut the sheaves of paddy while she would cull the rice.

But then, this fleeting period of peace, too, eluded her when her mother, weary of upkeeping a daughter, without much income, married her off to a man her father's age in a place called Karandih. Postobala was at the most 10-11 years old at the time. Unable to take it any more Postobala's health bucked under the pressure. Fever gripped her frail young body. She was taken to Manbazar hospital. But there, the young girl was subjected to a forced ligation in full knowledge of her mother. "Ora chiro kaaler jonyo amaar 'Maa' daak shona bondho kore dilo" She told me, her eyes betraying the glint of long pent-up tears. (They put an end to all possibilities of my becoming a mother some day)

With this began a new chapter, a new phase in Postobala's life. She was told to learn singing and dancing. The physical abuse and torture went on unabated. Desperate to live Posto ran away to a place called Metelya in Manbazar itself. There she worked in the houses of people as a charwoman. She was given two meals a day, one saree during the Durga Puja and one rough soap in 8 days. And Postobala made do with this. But the perils of life seemed to loom large again as $\mathrm{Kaki}$ - the woman Posto worked for-prepared to sell her off for a sum of Rs 10000 . At this juctur, there appeared Bijoy, brother to the woman Posto called Kaki. Bijoy was a bajandar, or musician of Jhumur. He expressed his desire to take Posto away with him to his own place where he already had a family — his wife Kalindi, and two sons. Posto protested — she was not in love with this man—-so she didn't see much justification in running along with him. 


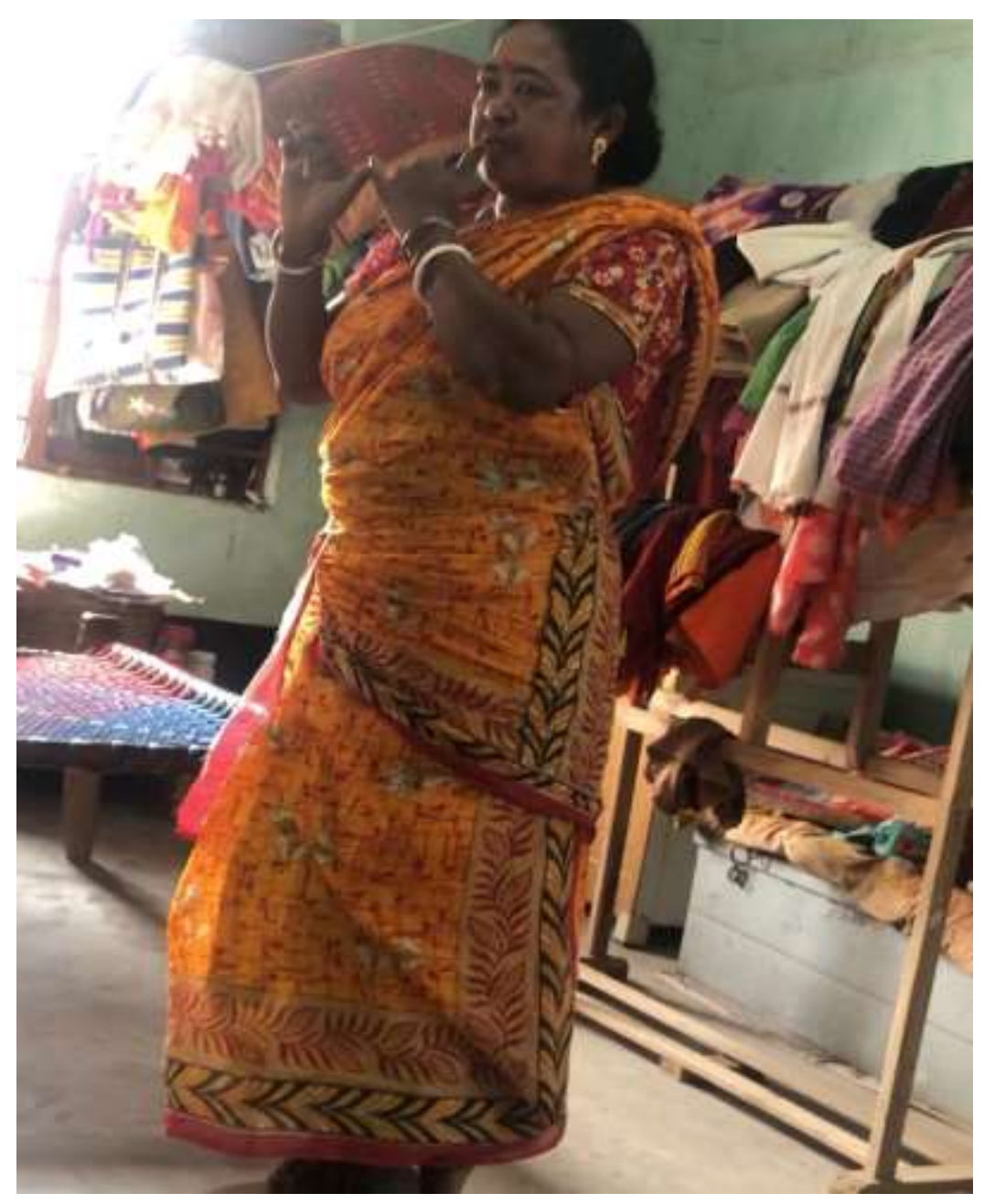

An impromptu performance by Postobalain her house for the interview.

Posto realized that in order to see better days she had to be economically independent. There was one thing she could do- one thing she had seen her mother doing — the one thing that could get her a living — being a Nachni. By then 18 or 19 years old, Postobala in 1983, came over to Bijoy's house. A furore of opposition greeted her from Bijoy's furious wife and family. As it was she was considered one of the untouchables - so much, so that if she happened to touch drinking water, the water was poured away. People made sure that they did not have to cross even her shadow. Bijoy's family refused to provide much food or shelter to Postubala. Under these precarious circumstances, Postobala started living as Nachni with Bijoy as her Rasik in a room close by but separate from the living quarters of Bijoy’s family. 
Postobala concentrated on turning herself into a full-fledged Nachni. At that time, the Nachnis who were making news in the Jhumur world were Shindhubala Devi-she was awarded the Lalan Prize by the Govt. of West Bengal. Postobala stayed with her for three months and learnt all she could from Shindhubala. She used to watch how Shindhubala danced, how she sang, the alluring slant of her eyes, her winning ways, her footwork. Postobala also avidly watched the dance programmes of her seniors like Bimala, Sushila, balika, parvati, Malabati, Butandevi, Bhanumati and Sandhyadevi. So earnest was Postobala in her efforts to learn from these established Jhumur Nachnis, that she would walk all the 50 kilometers from Dumari, where she stayed, to Balarampur. With a twinkle in her eyes during my interview with her, she said she would watch films too, whenever she could spare the money, to see and learn from the lithe and graceful dance styles of celluloid veterans like Hema Malini, Asha Parekh and Vyjaynthimala Bali.

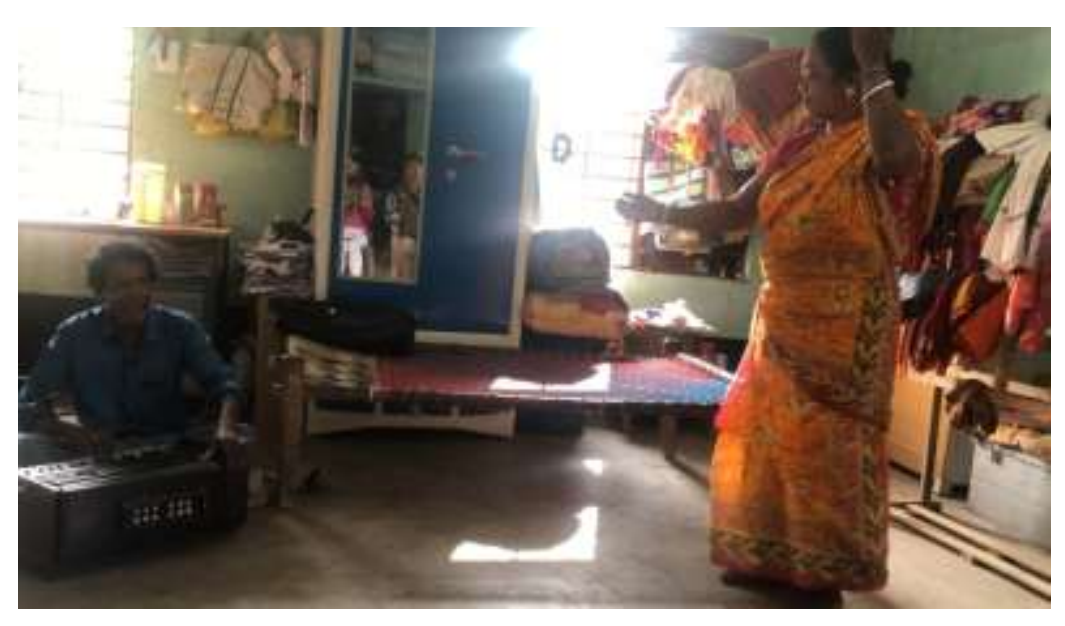

An impromptu performance with only Rasik Bijoy on the harmonium. In a stage performance there would be Damama, Kartal, Dholki, and Ghungur would be strapped on the feet of the Nachni.

When she, along with Bijoy as her Rasik, began to hold programmes on her own, money only trickled in. Around 1990, a programme would bring her all of Rs 50. In recent times, a 
dance programme earns her around Rs 8000 to 9000 . Sometimes she earns up to Rs 12000 too, if destiny favours. But that earning has to pay for myriad expenses too like conveyance to and from the site of programme, and food for everyone. Each Bajandar has to be paid around Rs 500 per programme. Over and above that, Nachni programmes are few and far between. So life doesn't look very hunky-dory as far as the economic part is concerned.

However, whatever Postubala and her Rasik Bijoy Karmakar earned, they brought to Bijoy's family. But happiness was still far behind. Insane with jealousy, Bijoy's wife, Shamola Karmakar, filed a case against her husband in court of law. Bijoy was apprehended by the court for three months before Postubala bailed him out with her meager stock of hard-earned money.

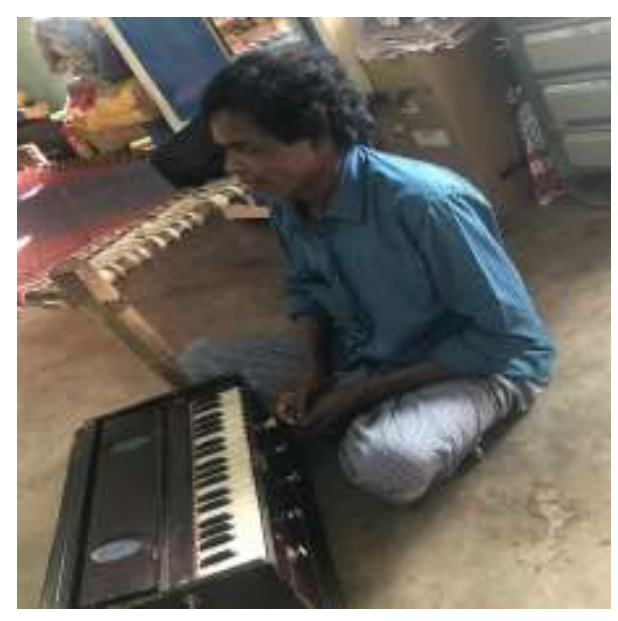

Bijoy Karmakar,

\section{Rasik for Postobala Karmakar}

Not to be outdone, Shamola told the court that Bijoy owned 10 quintals worth of paddy, 5 quintals of rice, 2 goats as well as a lot of musical instruments in a bid to gain a share of them. But her plans were foiled once the court, on investigation, came to know that her claims were not true. The matter was then settled mutually. 
Since then, things have looked up marginally for Postubala. She came in touch with the Durbar Mahila Samity with Dr Subrata Jana as Director and Advisor. She has been chosen as the District Secretary of the committee, which post has incidentally acquired her the little one-roomed building she stays in at present as living quarters.

In 2018, she was awarded the Lalan Award. She has also been featured in programmes like 'Tomare Salaam' and 'Dadagiri' and 'Didi No 1' on Television. She also gets a stipend of Rs 1000 per month that gets transferred to her bank account by NEFT.

But all said and done, one wonders whether that one thousand rupees even come close to what can be called a respectable sustenance of a human being who has proven herself worthy of the Lalan Prize among other accolades. Even today Postubala has to walk up to the nearby rice mill every evening to gather the husks they throw away daily so that she can sift through them in the hope of finding a handful of rice to cook for herself and her Rasik...

\section{Conclusion}

The tradition of Nachni has to be talked about more. The more it is talked of, the more people will understand the culture and that will be one step towards acknowledgement. Michel Foucault once said in his Archaeology of Knowledge that a discourse never takes place if a topic is not talked about. Not talking about a topic shoves it gradually to the point of taboo. And any possibility of a discourse gets nipped in the bud.

That is all the more why the Nachni has to be talked of. Her art has to be talked of. The life has to be documented. The world has to know her. The world has to help her find her identity. 


\section{Works Cited}

Foucault, Michel. The Archaeology of Knowledge. Routledge, 1972.

Karmakar, Postobala. Interview. Conducted by Aparajita Hazra, 28 November, 2019.

Pictures from the interview on $28^{\text {th }}$ November, 2019: 